\title{
The Efficient Pre- and Post-Operative Healthcare Strategies for Sleeve Gastrectomy Patients
}

\author{
Taha Anbara* \\ Department of Surgery, Erfan Niayesh Hospital, Iran
}

Submission: May 23, 2021; Published: June 11, 2021

*Corresponding author: Taha Anbara, Department of Surgery, Erfan Niayesh Hospital, PC 1476919491, No. 17, Bahar Intersection, Imam Hossein St., after Kabiri Tameh Blvd., Niayesh Gharb Highway, Tehran, Iran

\section{Abstract}

Bariatric surgery is an uprising approach as a reliable choice for weight loss, resulting in a significant remission in almost all obesity-related comorbidities. However, bariatric procedure is a minimal invasive surgery with trivial rates of complications; surgeons would be able to prevent comorbidities in patients with efficient interventions. We aim to mention our experiences on the management of post-operative complications including psychological disorders, hair loss, insufficient weight loss, bleeding, nutritional deficiencies and gastroesophageal reflux, and embolism.

Keywords: Bariatric surgery; Sleeve gastrectomy; Obesity; Complications

Abbreviations: RYGB: Roux-en-Y Gastric Bypass; AGB: Adjustable Gastric Band; BS: Bariatric surgery; LSG: Laparoscopic Sleeve Gastrectomy; T2D: Type 2 Diabetes; COPD: Chronic Obstructive Pulmonary Disease; GERD: Gastroesophageal Reflux Disease; HHR: Hiatal Hernia Repair; DVT: Deep Venous Thrombosis

\section{Introduction}

Obesity is one of crucial challenges in the world with a tripled prevalence in comparison to the last 40 years [1]. One of the a potential solutions for people with BMI higher than 40 is surgical methods which the most common types are Roux-en-Y Gastric Bypass (RYGB), Adjustable Gastric Band (AGB), and Laparoscopic Sleeve Gastrectomy (LSG) [2]. Patients usually experience around $50 \%$ excessive weight loss after operation [3]. Although, Bariatric surgery (BS) has a huge number of benefits for patients resulting in improvement in quality of life, weight loss and in overall metabolic pathways in almost all organs, but it has a series of short-term and long-term complications including malnutrition, bleeding, insufficient weight loss, Emboli, and mental disorders [4]. The lack of standard protocol for management of weight regain, consensus statements and guidelines leads to poor reporting and understanding of the significance of comorbidities after Bariatric surgery. In this article, we aim to mention the most efficient strategies that we hired before and after SG procedure in management of post-operative complications.

In order to prevent frequent complications, first of all, we have a very restrict assessments before surgery including socio- demographic conditions, clinical parameters, mental evaluations and diagnosis of anatomical abnormalities. Collecting baseline clinical data including age, gender, BMI, weight, height, prior surgery history, smoking and drink habits, type 2 diabetes (T2D), Fatty liver, chronic obstructive pulmonary disease (COPD), hypertension, hyperlipidemia, arrhythmia, sleep apnea, asthma, Gout, reflux disease, cholelithiasis, and cardiovascular disorders would help us to determine the best treatment approaches for patients [5]. For instance, in subjects suffering from gastroesophageal reflux disease (GERD), a concomitant hiatal hernia repair (HHR) and SG can be performed to decline AntiReflux medications use after the surgery that can be result from increased intra-abdominal pressure in bariatric surgery patients. Secondly, endoscopic evaluation may help us to have a good vision about patient's anatomical issues and choose better options during and after surgery. Finally, psychiatrists evaluate patient's mental parameters such as depression, eating disorders before surgery in our center. This will help us to prescribe suitable medications and prevent weight regain owing to problematic eating behaviors after operation [5]. During the surgery, an additional running suture beside the staple line with an absorbable threat prevents 


\section{Current Research in Diabetes \& Obesity Journal}

bleeding and possible even the risk of leakage. Anti-embolism stockings, in order to prevent deep venous thrombosis (DVT) are always in use.

In addition, recommended doses of either Enoxaparin or Rivaroxaban are injected to prevent emboli in bariatric patients [6-8]. Attention is acquired during dissecting of the omental blood vessels to prevent a damage of the right gastroepiploic artery. Intraluminal conditions, such as bleeding, can be monitored with Intraoperative gastroscopy and gas insufflation can be hired to detect leakage. Considering these strategies declined the incidence of the bleeding following SG to $2.80 \%$ in all ages and both males and females [5,9]. Based on reports, the rate of bleeding following SG ranges from 1.16 to $10.0 \%$ [10,11]. As far as nutritional deficiencies are concern, patients are diagnosed with pre- and post-operative deficiencies in Iron, Vitamin D, Zinc, Vitamin A, and Vitamin C in younger groups and Zinc, Iron, Vitamin A, Vitamin E, Vitamin C, and Vitamin D in subjects older than 45 years old [12-14].

Nutritional deficiency is one of the most frequent postoperative complications among bariatric patients resulting in several consequences such as hair loss, anemia, fatigue, and several physiological disorders [4]. Identification and correction of micronutrients deficiencies was essential for treating hair loss and other complications. Our dietetic experts designed specific supplements for bariatric patients. Our patients stated to be benefited from supplements. Indeed, most patients stopped hair loss after prescription of vitamin and mineral supplements after the first postoperative year after SG. Our supplement are bought from a pharmaceutical company and contains principal ingredients including Iron, Biotin, Zinc, Selenium, Folic acid, Riboflavin, Vitamin B12, Vitamin B1, Vitamin A, Vitamin E, Vitamin C, and
Vitamin D. Further studies are required to prove the importance of nutritional supplements in remission in other complications such as depression, eating disorders, and insufficient weight loss.

Physical medicine experts in our center help patients with insufficient weight loss with various interventions including supervised aerobic exercises for example, bicycling, brisk walking and swimming, and practicing meditation as well as endurance activities based on patients' age and BMI. There are enormous publications reporting $80 \mathrm{~min}$ supervised strength training, aerobic and stretching exercise, and endurance activities can be particularly effective at reducing visceral adipose tissue. On the other side, $120 \mathrm{~min}$ of supervised aerobic exercise for 6 to 10 months and started 1 to 3 months after surgery can strongly prevent weight regain in a long-term period following Bariatric surgery [15-17]. Such findings highlight the importance of measuring and documenting physical activity levels after Bariatric surgery.

Also, psychiatrists support bariatric patients suffering eating disorders, depression, and anxiety. Most of patients complain about grazing or binge eating disorders after bariatric surgery. While, the most principal dietary problems after surgery can be divided into 13 groups including erratic eating, meal skipping, unhealthy food and beverage selections, inappropriate portions, alcohol use, insufficient protein and fiber intake, drinking fluids with meals, grazing, binge eating, night eating syndrome, postsurgical eating avoidance disorder, soft-food syndrome, and eating disorders such as bulimia nervosa and anorexia nervosa (63) and needs to be diagnosed by obesity medicine experts in order to hire proper interventions. Table 1 illustrates the problematic eating behaviors associated with weight regain and intervention approaches following bariatric surgery.

Table 1: Problematic eating behaviors associated with weight regain and intervention approaches following bariatric surgery [18].

\begin{tabular}{|c|c|c|}
\hline Eating Behavior & Problem & Intervention \\
\hline Erratic eating & Inconsistent/unplanned eating schedule & $\begin{array}{l}\text { Preplan approximate timing and appropriate spacing of meals } \\
\text { throughout the day based on daily schedule }\end{array}$ \\
\hline Meal skipping & $\begin{array}{l}\text { Not eating for an extended time period leading to sub- } \\
\text { sequent hunger and overeating }\end{array}$ & $\begin{array}{c}\text { Plan meals ahead of time; create a shopping list to ensure } \\
\text { selected food and appropriate amounts are available to prepare } \\
\text { these meals }\end{array}$ \\
\hline $\begin{array}{l}\text { Unhealthy food and } \\
\text { beverage selections }\end{array}$ & $\begin{array}{c}\text { Frequent intake of high-calorie/processed meals and } \\
\text { snacks including fast food/take-out, fried food, concen- } \\
\text { trated sweets, and refined carbohydrates; calorie-rich } \\
\text { beverages such as soda and juices }\end{array}$ & $\begin{array}{l}\text { Education on balanced meal preparation containing protein } \\
\text { and fiber-rich sources to help optimize satiety; encourage cook- } \\
\text { ing classes and/or online cooking resources }\end{array}$ \\
\hline Nibbling/Grazing & $\begin{array}{l}\text { Continuous/repetitive and unplanned eating of modest } \\
\text { portions of food throughout the day; often associated } \\
\text { with previous binge-eating behaviors; leads to exces- } \\
\text { sive cumulative energy intake }\end{array}$ & $\begin{array}{l}\text { Avoidance of skipping meals; appropriate meal portion sizes } \\
\text { (1/2-1 cup). Identify triggers including stress, boredom, and } \\
\text { emotional factors or engaging in other activities such as watch- } \\
\text { ing television }\end{array}$ \\
\hline Night eating & $\begin{array}{l}\text { Consuming more calories before sleep favors positive } \\
\text { energy balance and weight gain }\end{array}$ & $\begin{array}{l}\text { Schedule time for meals during the day; self-monitor using food } \\
\text { journal }\end{array}$ \\
\hline Inappropriate portions & $\begin{array}{l}\text { Portion sizes beyond the feeling of fullness resulting in } \\
\text { discomfort }\end{array}$ & $\begin{array}{l}\text { Weigh and measure foods, use smaller plates and utensils, and } \\
\text { limit volume to } 1 \text { cup of food per meal }\end{array}$ \\
\hline Alcohol use & $\begin{array}{l}\text { Excess nonnutritive calories; promotes increased } \\
\text { hunger, food cravings, and compromises judgment } \\
\text { regarding proper food selection }\end{array}$ & $\begin{array}{l}\text { Avoid or limit alcohol consumption; consider referral to treat- } \\
\text { ment program if unable to control behavior }\end{array}$ \\
\hline
\end{tabular}




\section{Current Research in Diabetes \& Obesity Journal}

\begin{tabular}{|c|c|c|}
\hline $\begin{array}{c}\text { Insufficient protein and } \\
\text { fiber intake }\end{array}$ & $\begin{array}{c}\text { Protein and fiber promote optimal satiation; pro- } \\
\text { tein-rich foods optimize muscle integrity and energy } \\
\text { metabolism }\end{array}$ & $\begin{array}{c}\text { Education on quality sources of protein and fiber; assist with } \\
\text { meal planning to achieve appropriate intake }\end{array}$ \\
\hline $\begin{array}{c}\text { Drinking fluids with } \\
\text { meals }\end{array}$ & $\begin{array}{c}\text { Potential enlargement of the gastric pouch and outlet } \\
\text { with repeated behavior; leads to rapid emptying of the } \\
\text { stomach }\end{array}$ & $\begin{array}{c}\text { Delay fluid intake at least 30 minutes after consuming solid } \\
\text { food }\end{array}$ \\
\hline
\end{tabular}

\section{Conclusion}

Cumulatively, not only bariatric surgery is safe with significant remission in comorbidities in younger and older ages, but also the advantages outweigh the drawbacks. Although postoperative complications are undeniable but with frequent follow-up visits and cutting-edge interventions can be solved.

\section{References}

1. Helvaci N, Eyupoglu ND, Karabulut E, Yildiz BO (2021) Prevalence of obesity and its impact on outcome in patients with COVID-19: a systematic review and meta-analysis. Front Endocrinol (Lausanne) 12: 82.

2. Kheirvari M, Akbarzadeh I, Eshghjoo S, Yazdannasab M, Alaniz RC, et al. (2020) Diagnostic Value of Erythrocyte Sedimentation Rate Levels as a Predictor of Staple-Line Leakage in Bariatric Surgery. Bariatr Surg Pract Patient Care 5(4): 231-235.

3. Amiki M, Seki Y, Kasama K, Hashimoto K, Kitagawa M, et al. (2020) Revisional bariatric surgery for insufficient weight loss and gastroesophageal reflux disease: our 12-year experience. Obes Surg 30(5): 1671-1678.

4. Kheirvari M, Dadkhah Nikroo N, Jaafarinejad H, Farsimadan M, Eshghjoo S, et al. (2020) The advantages and disadvantages of sleeve gastrectomy; clinical laboratory to bedside review. Heliyon 6(2): e03496.

5. Anbara T (2021) The relationship between bleeding and age in Sleeve gastrectomy subjects. Obes Med 100344.

6. Rowan BO, Kuhl DA, Lee MD, Tichansky DS, Madan AK (2008) Anti-Xa levels in bariatric surgery patients receiving prophylactic enoxaparin. Obes Surg 18(2): 162-166.

7. Hamad GG, Choban PS (2005) Enoxaparin for thromboprophylaxis in morbidly obese patients undergoing bariatric surgery: findings of the prophylaxis against VTE outcomes in bariatric surgery patients receiving enoxaparin (PROBE) study. Obes Surg 15(10): 1368-1374.

8. Moore KT, Kröll D (2017) Influences of obesity and bariatric surgery on the clinical and pharmacologic profile of rivaroxaban. Am J Med 130(9): 1024-1032.

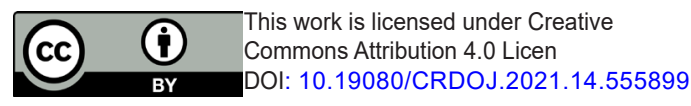

9. Stier C, Chen W, Chong TH, Yang J, Parmar C, et al. (2021) Step-By-Step Instructions for the Innovative Three-Port-Technique of Laparoscopic Sleeve Gastrectomy: How I Do It?

10. Janik MR, Walędziak M, Brągoszewski J, Kwiatkowski A, Paśnik K (2017) Prediction model for hemorrhagic complications after laparoscopic sleeve gastrectomy: development of SLEEVE BLEED calculator. Obes Surg 27(4): 968-972.

11. Lim E, Poh B, Chan WH, Eng A, Tham KW, Ganguly S, et al. (2016) Post-operative Bleeding Complications in Laparoscopic Sleeve Gastrectomy: Sources, Solutions and lessons learnt from a single cohort of patients. Surg Obes Relat Dis 12(7): S106.

12. Punchai S, Hanipah ZN, Meister KM, Schauer PR, Brethauer SA, et al. (2017) Neurologic Manifestations of Vitamin B Deficiency after Bariatric Surgery. Obes Surg 27(8): 2079-2082.

13. Tabbara M, Carandina S, Bossi M, Polliand C, Genser L, et al. (2016) Rare Neurological Complications After Sleeve Gastrectomy. Obes Surg 26(12): 2843-2848.

14. Via MA, Mechanick JI (2017) Nutritional and Micronutrient Care of Bariatric Surgery Patients: Current Evidence Update. Current obesity reports 6(3): 286-296.

15. Panosian J, Ding SA, Wewalka M, Simonson DC, Goebel-Fabbri A, et al (2017) Physical activity in obese type 2 diabetes after gastric bypass or medical management. Am J Med 130(1): 83-92.

16. Coleman KJ, Caparosa SL, Nichols JF, Fujioka K, Koebnick C, et al (2017) Understanding the capacity for exercise in post-bariatric patients. Obes Surg 27(1): 51-58.

17. Creel DB, Schuh LM, Reed CA, Gomez AR, Hurst LA, et al. (2016) A randomized trial comparing two interventions to increase physical activity among patients undergoing bariatric surgery. Obesity 24(8): 1660-1668.

18. Istfan NW, Lipartia M, Anderson WA, Hess DT, Apovian CM (2021) Approach to the Patient: Management of the Post-Bariatric Surgery Patient with Weight Regain. J Clin Endocrinol Metab 106(1): 251-263.

Your next submission with Juniper Publishers
will reach you the below assets
- Quality Editorial service
- Swift Peer Review
- Reprints availability
- E-prints Service
- Manuscript Podcast for convenient understanding
- Global attainment for your research
- Manuscript accessibility in different formats
( Pdf, E-pub, Full Text, Audio)
- Unceasing customer service
Track the below URL for one-step submission
https://juniperpublishers.com/online-submission.php

